\title{
OCCUPANCY BY HYLAEUS OF SUBTERRANEAN HALICTID NESTS (HYMENOPTERA: APOIDEA) ${ }^{1}$
}

\author{
By Edward M. Barrows \\ Department of Entomology, University of Kansas \\ Lawrence, Kansas 66045
}

Hylaeus (Colletidae) is well known to nest in various preformed cavities. It is most commonly reported in hollow stems (Stoekhert, 1933; Malyshev, 1936; Michener, 1965; Stephen et al., 1969) but also may occupy cynipid wasp galls (Stoekhert, I933; Laroca, 197 I) and dead wood (Perkins, I899; Michener, 1965). However, nest sites are not limited to plant materials. Smith ( I855) reported cells in hollow pieces of "flint stone"; Ferton (1932), in earthworm burrows; and Perkins (I899), in ground. The present paper concerns nests of $H$. bisinuatus ${ }^{2}$ in burrows of a halictine bee in an earthen bank; this is the first record of Hylaeus occupancy of nests of another hymenopteran.

H. bisinuatus has also been found in North America nesting in soda-straw traps and nail holes (R. R. Snelling, pers. comm.) and in Europe in hollow briar (Rubus) stems (Stoekhert, 1933). Thus this species evidently has behavior which is flexible enough to enable it to nest in a variety of preformed holes in a wide geographical area.

In early July to early August, 1974, six nests of $H$. bisinuatus were found among those of Lasioglossum (Dialictus) zephyrum (Halictidae: Halictinae) in a nesting aggregation in vertical banks of the Kansas River, near Eudora, Douglas County, Kansas. Although the Lasioglossum nest aggregation is enormous, extending for about I km up and down the river, all the Hylaeus nests were found in about IO square meters where the bank faces northwest.

The burrows occupied by $H$. bisinuatus were obviously former nests of $L$. zephyrum. In two nests vacant cells of $L$. zephyrum were near those used by $H$. bisinuatus; abandoned cells of $L$. zephyrum probably would have been found in all nests by following main burrows farther into the soil. Cells of Hylaeus were constructed in cells of the Lasioglossum still having the shape and wax-like lining

\footnotetext{
${ }^{1}$ Contribution No. 1580 from the Department of Entomology, University of Kansas, Lawrence, Kansas.

${ }^{2} \mathrm{H}$. bisinuatus (Förster, 1871), described from Europe, is a senior synonym of $H$. stevensi (Crawford, 1913), described from North America, where it is probably adventive ( $R$. R. Snelling, pers. comm.).

Manuscript received by the editor, April 5, 1975
} 
characteristic of the halictine. The longitudinal axes of the burrows and cells of the nests were horizontal as is typical for nests of $L$. zephyrum in vertical banks (Batra, 1966). Burrows and nest entrances were similar in size to those of L. zephyrum. Thus there is no evidence that the Hylaeus did any nest excavation; it appears to have merely used available nests for its own purposes. Furthermore there is no evidence that the Hylaeus entered occupied Lasioglossum nests, although this possibility exists.

All six Hylaeus nests were discovered after their entrances had been closed, each with a sheet of a cellophane-like material flush with the surface of the soil bank. The sheets had striations radiating from their centers and small openings along their margins. A female of H. bisinuatus was discovered licking across a nest entrance already closed by a "cellophane" sheet. Evidently she was finishing the closure. She revolved around the entrance 3 times in 18 minutes while she licked 22.5 times per minute $(\mathrm{n}=2 \mathrm{~min})$ across the sheet; during this time she took occasional rests of several seconds each. During each lick the tip of her proboscis moved from her midventral area to a point in front of her head.

For identification she was captured before she finished the closure and two days later (on 5 July) her nest was examined (Fig. I). All three of the cells in her nest were provisioned with a soft yellow material, most likely a mixture of pollen and nectar as is used by

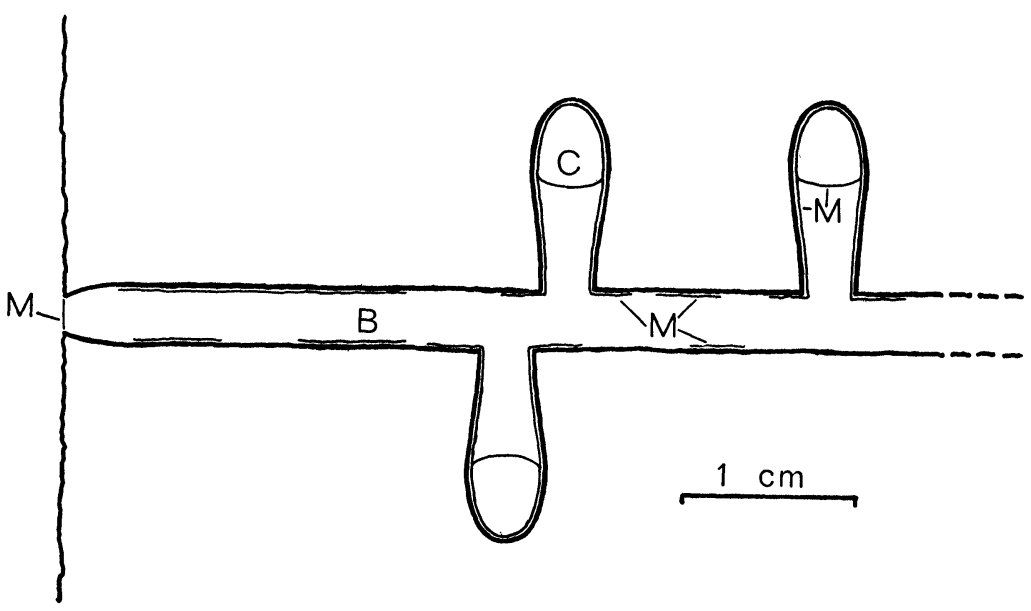

Fig. 1. Top view of a nest of Hylaeus bisinuatus made in a nest of Lasioglossum zephyrum; B, main burrow ; C, Hylaeus cell inside Lasioglossum cell; M, cellophane-like membrane secreted by the Hylaeus. 
other Hylaeus, and each contained a larva. One larva became a prepupa on $6 \mathrm{July}$, a pupa on $7 \mathrm{July,}$ and an adult female on $14 \mathrm{July}$; the other larvae were small and died.

Nests had from I to 3 Hylaeus cells ( $\overline{\mathrm{x}}=\mathrm{r} \cdot 7, \mathrm{n}=6$ nests), each in a different Lasioglossum cell (Fig. 2). Both Hylaeus cells which were measured were $5 \mathrm{~mm}$ long and $3.5 \mathrm{~mm}$ in maximum diameter and at the ends of Lasioglossum cells. The walls of the cells had old wax-like lining deposited by $L$. zephyrum (Batra, 1966). H. bisinuatus laid down two other cell linings to form its cells: ( $\mathrm{I}$ ) a very thin "cellophane" layer visible under a microscope $(30 X)$ only when light strikes it at a certain angle and (2) a slightly thicker "cellophane" layer over the first one. This thicker layer also covered walls of lateral burrows and parts of main burrows. A sheet of what appeared to be this same second layer closed off each cell and with the unaided eye the halictine cells appeared to be constricted where such a sheet was placed. Complete removal of the cellophane-like material, however, shows the unmodified form of the halictine cell.

$H$. bisinuatus used cells of $L$. zephyrum that were 0.8 to $4.5 \mathrm{~cm}$ $(\bar{x}=3.3 \mathrm{~cm}, \mathrm{n}=6$ nests $)$ from the nest entrances. Since $L$. zephyrum constructs cells this close to the surface of a soil bank only in spring or early summer, the Hylaeus must have used earlyseason Lasioglossum cells made in the year of this study or possibly in the previous year.

\section{AckNowledgments}

I thank Mr. Roy R. Snelling of the Los Angeles County Museum of Natural History for identifying Hylaeus bisinuatus. He and Drs. Charles D. Michener and William J. Bell and Ms. Marjorie R. Chabot made important suggestions regarding this note. It is a byproduct of National Science Grant GB-38502 (W. J. Bell and C. D. Michener, coprincipal investigators).

\section{Literature Cited}

BATRA, S. W. T.

1966. The life cycle and behavior of the primitively social bee Lasioglossum zephyrum (Halictidae). Univ. Kansas Sci. Bull. 46: 359-423.

Ferton, C.

1923. La vie des abeilles et des guêpes, oeuvres choisies, groupées et annotées par Etienne Rabaud et François Picard. Etienne Chiron, ed., 40 Rue de Seine, Paris. 376 pp. 
LAROcA, S.

1971. Notas sôbre a biologia de Hylaeus cecidonastes Moure (Hymenoptera, Apoidea). Rev. Brasil. Biol. 32: 285-290.

Malyshev, S. I.

1936. The nesting habits of solitary bees (a comparative study). Eos 11 : 201-309.

Michener, C. D.

1965. A classification of the bees of the Australian and South Pacific Regions. Bull. Amer. Mus. Nat. Hist. 130: 1-362.

Perkins, R. C. L. in Perkins, R. C. L. and A. Forel.

1899. Fauna Hawaiiensis or the zoology of the Sandwich (Hawaiian) Isles. Vol. 1, Part 1. Hymenoptera, Aculeata. Cambridge Univ.

SMITH, F. Press. 122 pp.

1855. Catalogue of British Hymenoptera: Part 1 Apidae-bees. London. 252 pp.

Stephen, W. P., G. E. Bohart, and P. E. Torchio.

1969. The biology and external morphology of bees with a synopsis of the genera of northwestern America. Agric. Exp. Station, Oregon St. Univ., Corvallis. 140 pp.

STOEKHERT, F. K.

1933. Die Bienen Frankens (Hym. Apid.) Beiheft Deuts. Entomol. Zeit. 1-294. 

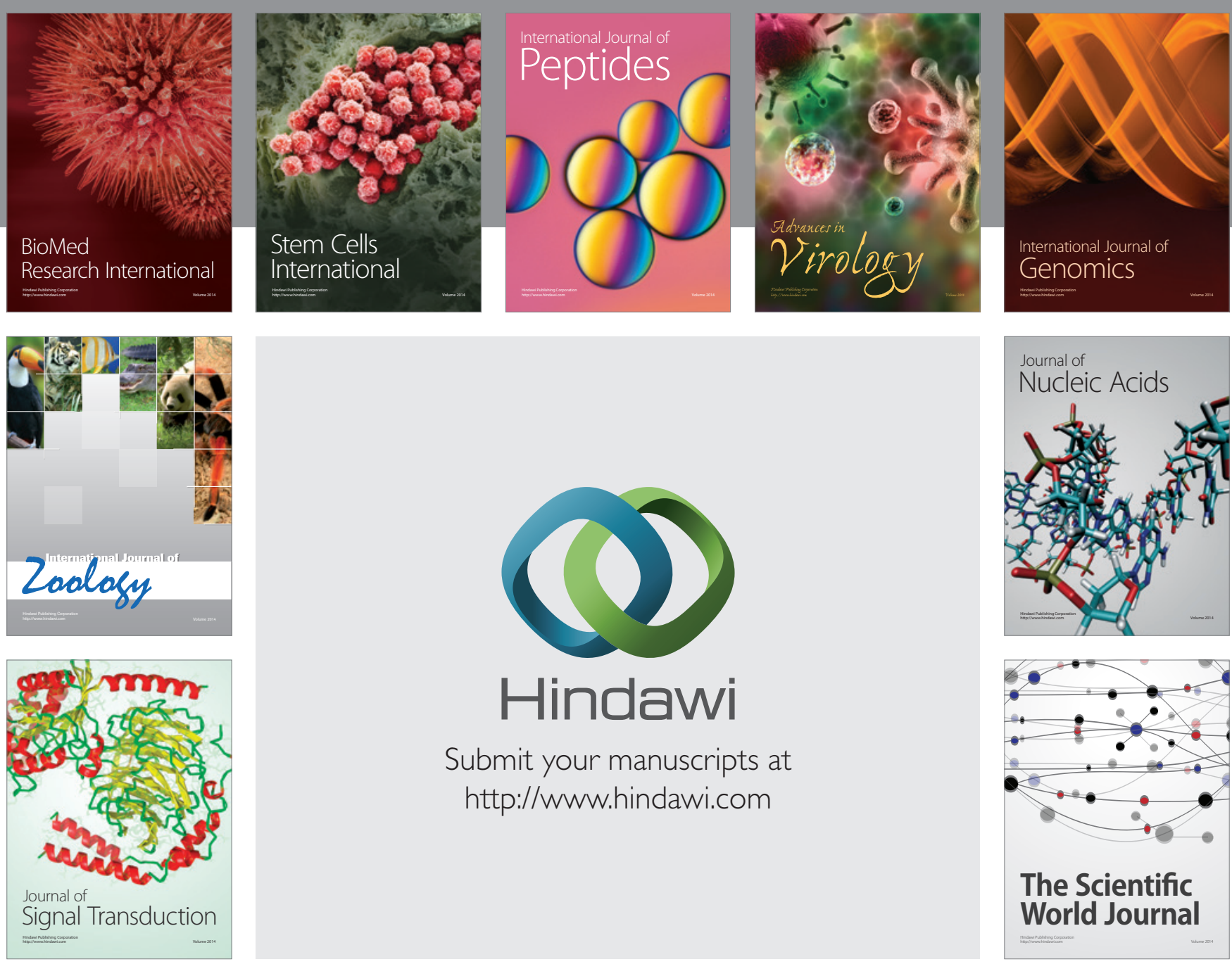

Submit your manuscripts at

http://www.hindawi.com
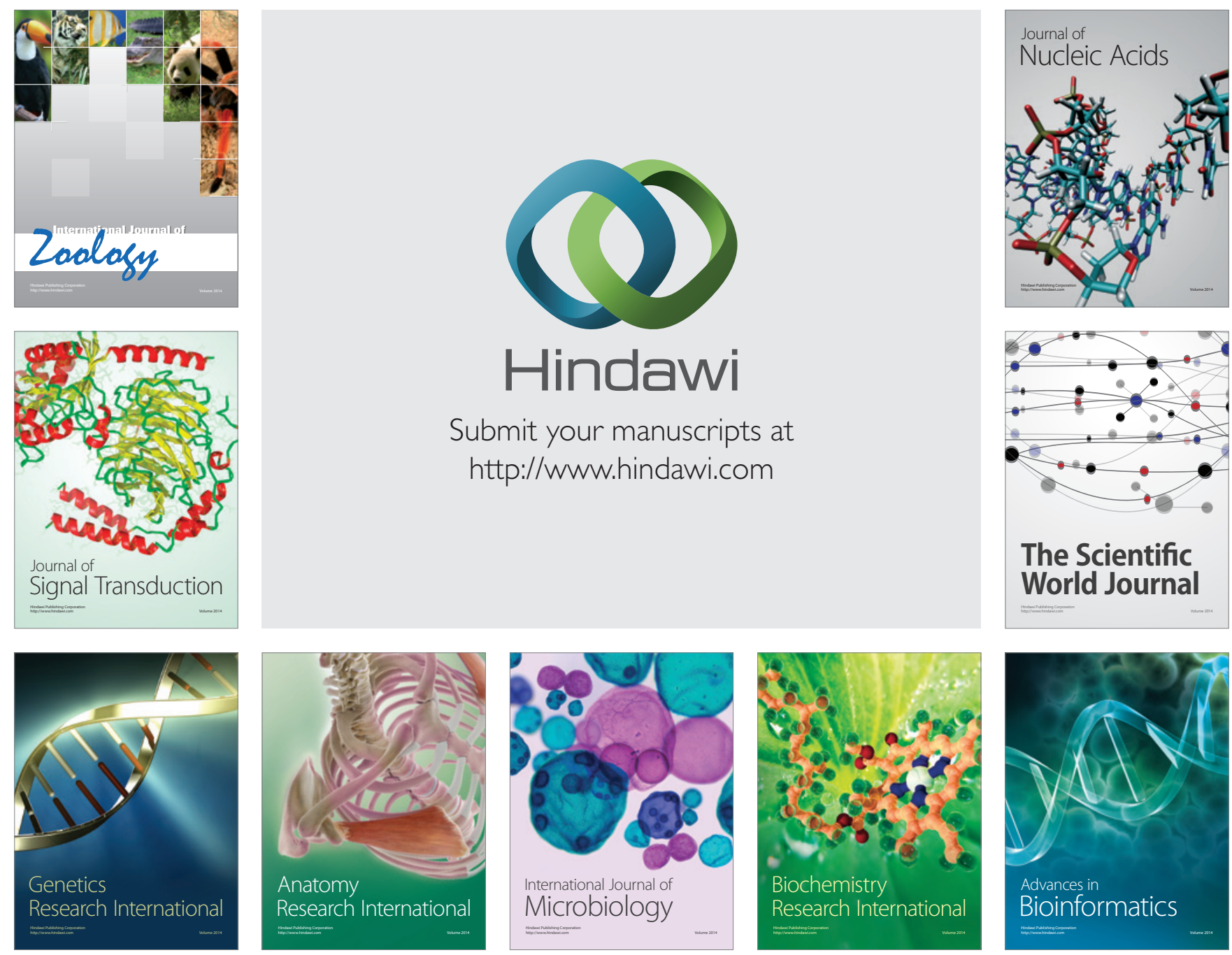

The Scientific World Journal
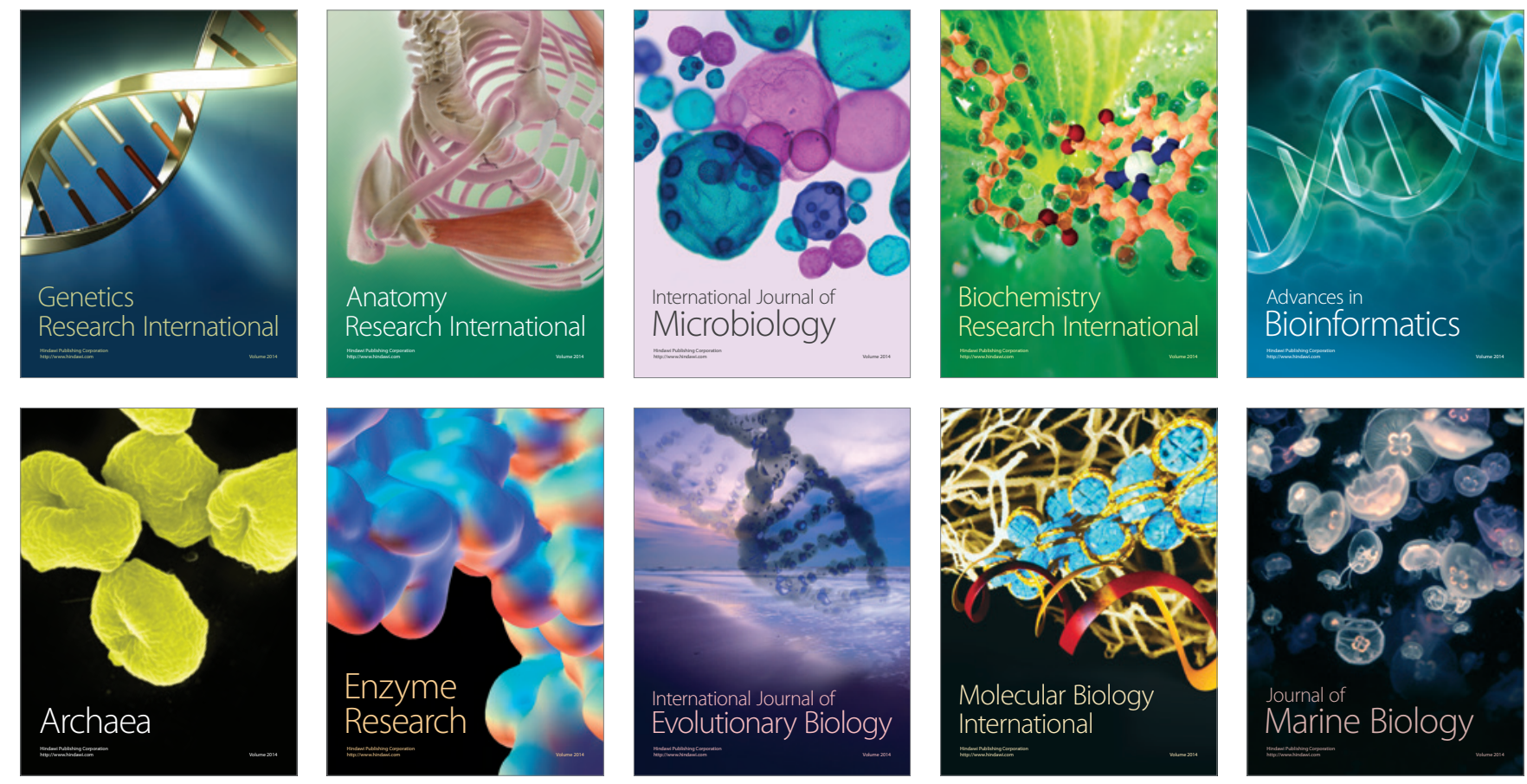